\title{
A (IN) \\ CONSTITUCIONALIDADE \\ DA POLÍTICA E DO \\ SISTEMA NACIONAL DE \\ PARTICIPAÇÃO SOCIAL
}

THE (UN)CONSTITUTIONALITY OF THE NATIONAL POLICY AND FRAMEWORK OF SOCIAL PARTICIPATION

LA (IN)CONSTITUCIONALIDAD DE LA POLÍTICA Y DEL SISTEMA NACIONAL DE PARTICIPACIÓN SOCIAL

Giovani da Silva Corralo ${ }^{1}$

$1 \quad$ Especialista em Direito Municipal pela UFRGS. Mestre e Doutor em Direito do Estado pela UFPR. Professor da Graduação e do Programa de Mestrado em Direito da Universidade de Passo Fundo - Passo Fundo, Rio Grande do Sul, Brasil. Professor convidado do Programa de Mestrado em Direito da Universidade Agostinho Neto - Angola. E-mail: gcorralo@upf.br. 
Resumo: O presente artigo tem por objetivo o estudo da (in) constitucionalidade da política e do sistema nacional de participação social instituído com o Decreto 8.243/2014, o que se mostra de extrema relevância, uma vez que este assunto se encontra no centro de reflexões no mundo político e jurídico. Longe de se perquirir uma pureza metodológica, inadequada nos dias atuais, prepondera o método dialético na elaboração e no desenvolvimento deste trabalho científico. Para tanto, discorre-se sobre a democracia, seu desenvolvimento histórico e conformações atuais. Em sequência, perpassa-se ao estudo do Decreto 8.243/2014 e aos respectivos mecanismos de participação social. Por fim, aborda-se a constitucionalidade do referido decreto, formalmente e materialmente. A conclusão apontou pela total compatibilidade do Decreto 8.243/2014 com a ordem constitucional brasileira na perspectiva formal e material.

Palavras-chave: Democracia participativa. Constitucionalidade. Política nacional de participação social. Sistema nacional de participação social.

Abstract: This paper investigates the (un)constitutionality of the national policy and framework of social participation, established by government Decree $8.243 / 2014$, which has proven to be highly relevant, as this subject is at the heart of reflections on the political and legal world. Far from seeking methodological purity, which is inadequate nowadays, the method used is dialectical in the elaboration and development of this scientific work. Thus, it discusses democracy, its historical development and its current conformations. It also analyses Decree $8.243 / 2014$ and the respective mechanisms of social participation. Finally, it addresses the constitutionality of this decree, in a material and formal way. The conclusion points out the total compatibility of Decree 8.243/201 with the Brazilian constitutional order, from a material and formal perspective.

Keywords: Democracy. Constitutionality. National policy of social participation. National framework of social participation. 
Resumen: El presente artículo tiene por objetivo el estudio de la (in)constitucionalidad de la política y del sistema nacional de participación social instituido por el Decreto 8.243/2014, lo que se muestra de extrema relevancia, considerando que este asunto se encuentra en el centro de las reflexiones en el mundo político y jurídico. Lejos de perquirir una pureza metodológica, inadecuada en los días actuales, en la elaboración y en el desarrollo de este trabajo científico prepondera el método dialéctico. Para ello se discurre sobre la democracia, su desarrollo histórico y conformaciones actuales. A seguir, se pasa al estudio del Decreto $8.243 / 2014$ y a los respectivos mecanismos de participación social. Por último, se aborda la constitucionalidad del referido decreto, formalmente y materialmente. La conclusión señaló la total compatibilidad del Decreto 8.243/2014 con el orden constitucional brasileño desde una perspectiva formal y material.

Palabras clave: Democracia participativa. Constitucionalidad. Política nacional de participación social. Sistema nacional de participación social.

\section{INTRODUÇÃO}

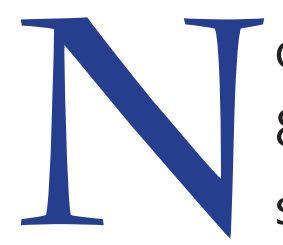

o dia 23 de maio de 2014 o governo federal publicou o Decreto 8.243/2014, que instituiu a política nacional de participação social e o respectivo sistema nacional de participação social. De imediato houve uma forte repercussão, especialmente no sentido de questionar a constitucionalidade do referido decreto presidencial, o que levou a fortes debates no Congresso Nacional e, até mesmo, à proposição de projeto de decreto legislativo a fim de sustar os efeitos do ato normativo em comento, além de medidas judiciais - ação popular - para suspender os seus efeitos. ${ }^{2}$

Na véspera de um processo eleitoral espera-se que este debate, eminentemente acadêmico, não seja contaminado por predisposições eleitorais, até mesmo 2 FOLHA DE SÃO PAULO ON-LINE. Disponível em: <http://www1.folha.uol.com.br/ poder/2014/06/1468178-devido-a-decreto-de-consulta-popular-oposicao-obstruira-votacoes-na-camara.shtml>. Acesso em: 22 jul. 2014. 
porque se assim fosse, muito provavelmente este pesquisador não fosse o mais adequado para efetivar a pesquisa e apontar as respectivas conclusões.

A questão não está pacificada, ainda mais nos meios políticos, o que salienta o relevo desta produção científica. Para tanto, é preciso refletir sobre o estágio atual da democracia brasileira, mormente quanto à democracia representativa e à democracia participativa. Mais do que isto, se requer uma leitura constitucionalmente adequada da democracia frente à Constituição de 1988.

Em sequência, perpassa-se ao estudo do Decreto 8.243/2014, a fim de compreender a sua aplicação, os institutos disciplinados e a sua validade no ordenamentojurídico brasileiro. Porfim, discorre-se sobrea (in)constitucionalidade do referido decreto sob as perspectivas formal e material. Sem crer em purezas metodológicas, prepondera o método dialético na elaboração deste artigo.

É necessária uma maior repercussão na academia jurídica das questões candentes dos espaços do direito e da política, uma vez que tais campos encontram-se indissociavelmente ligados. A dogmática jurídica, numa perspectiva crítica, é essencial para o amadurecimento institucional e para a maturação dos grandes debates nacionais. É o que se propõe, modestamente, nas reflexões deste trabalho científico.

\section{OS DESAFIOS DA DEMOCRACIA BRASILEIRA: ENTRE A REPRESENTATIVIDADE E A PARTICIPAÇÃO NA CONTEMPORANEIDADE}

Não há maiores questionamentos quanto à conformação brasileira como um Estado Democrático de Direito. É o que dispõe, textualmente, a Constituição Federal de 1988, a resguardar o regime democrático como uma cláusula pétrea. Mas isso não basta. A democracia pode ser concebida univocamente quanto ao seu sentido? Como a democracia avançou, desde o seu surgimento, há mais de dois mil anos? De que forma a Constituição Federal concebe a democracia brasileira? Estas e outras questões correlatas são alvo deste primeiro conjunto de reflexões. 
Não há um sentido unívoco para a conceituação da democracia nos dias atuais. A afirmação "I'm for democracy communicates virtually no information". ${ }^{44}$ Uma assertiva desta talvez possibilite a exclusão do apoio a regimes totalitários, calcados no terror e nas leis da natureza ou da história, bem conhecidos em meados do séc. $X X$, com os modelos alemão e soviético. ${ }^{5}$

A questão central é que os mais diversos países e nações arvoram-se na autointitulação de regimes democráticos. Aliás, tais confusões não ocorrem somente na atualidade. Aquele que foi o maior julgamento da história - o julgamento de Cristo - divide os estudiosos. Para o consagrado jurista Hans Kelsen, a sua condenação é um ônus da democracia. ${ }^{6}$ A leitura crítica de Gustavo Zagrebelsky, por sua vez, contraria o posicionamento de Kelsen ao afirmar que não é possível conferir a um julgamento às pressas, sem um devido processo legal, com sinais de manipulação, a característica de um processo democrático. ${ }^{7}$

É inequívoco que a compreensão do que seja a democracia mudou no decorrer dos séculos. O modelo da antiguidade que mais mereceu a atenção foi o ateniense - séc. IV e III a.C, forjado na participação dos cidadãos nos assuntos da cidade. Foi a chamada democracia direta. Entretanto, deve-se registrar que esta participação não fora tão ampla assim, pois a maior parte das pessoas adultas estavam excluídas, como é o caso dos escravos e das mulheres. ${ }^{8}$ Por mais que a famosa Oração Fúnebre de Péricles no ano 430 a.C. enalteça as virtudes da democracia ateniense, especialmente a participação do cidadão na vida pública e os debates públicos e transparentes acerca das questões da cidade, ${ }^{9}$ os principais expoentes da filosofia clássica - Platão e Aristóteles - não concebiam 3 LUMMIS, C. Douglas. Radical Democracy. Ithaca: Cornell University Press, 1996, p. 14.

4 "Ser favorável à democracia não representa maiores informações." (tradução nossa).

5 ARENDT, Arendt. Origens do Totalitarismo: antissemitismo, imperialismo, totalitarismo. São Paulo: Schwarcz, 2013, p.611-626.

6 KELSEN, Hans. A Democracia. São Paulo: Martins Fontes, 2000, p. 203-204.

7 ZAGREBELSKY, Gustavo. A Crucificação e Democracia. 1. ed. São Paulo: Saraiva, 2010, p. 32-33.

8 DURANT, Will. História da Filosofia. São Paulo: Companhia Editora Nacional, 1926, p. 25. BIELSCHWSKY, Raoni. Democracia Constitucional. 1. ed. São Paulo: Saraiva, 2013, p. 52. Segundo Will Durant: "De certo modo, não havia lá grande democracia a acusar, pois dos 400.000 habitantes de Atenas 250.000 eram escravos, sem quaisquer direitos políticos; e dos 150.000 homens livres ou cidadãos, só reduzido número se apresentava na Eclesia, ou assembleia geral, onde as coisas públicas eram debatidas e resolvidas." DURANT, Will. História da Filosofia, p. 25.

9 PÉRICLES. Oração Fúnebre. Disponível em: <http://pt.scribd.com/doc/54079555/ORACAO-FUNEBRE-PERICLES>. Acesso em: 10 jul. 2014. 
a democracia como a melhor forma de governo. Ao contrário, preferiam a aristocracia e compreendiam a democracia como uma forma de deterioração de modelos mais aprimorados. ${ }^{10}$

A democracia antiga não compreendia a liberdade individual, mas somente a pessoa como integrante de uma coletividade, da qual não escapava sequer a vida privada. A pessoa, na sua integralidade, pertencia ao todo coletivo. ${ }^{11}$ A democracia dos modernos, por sua vez, tem por escopo uma concepção individualista da pessoa humana, ${ }^{12}$ próprio da modernidade e da reafirmação da razão e da autonomia da pessoa humana, em termos de liberdade individual, mesmo que englobada por uma racionalidade instrumental e eurocêntrica. ${ }^{13}$ Esta democracia moderna, fortemente enraizada na contemporaneidade, está calcada na escolha de representantes, em processos eleitorais periódicos, abertos à participação daqueles que possuam os requisitos legais. Os escolhidos encontramse legitimados para decidir em nome da coletividade.

Em outras palavras, segundo Norberto Bobbio "por democracia os antigos entendiam a democracia direta, os modernos, a democracia participativa." ${ }^{14}$ Robert Dahl afirma que a lógica da representação surge na Europa do Norte, nos séc. VII a XI, com o povo viking, seguido pelos países escandinavos no séc. XV e pela própria Inglaterra a partir do séc. XIII. ${ }^{15}$ De qualquer forma, a democracia, nos dias de hoje, de cunho eminentemente representativo, se assenta com as revoluções burguesas do séc. XVIII, especialmente na Europa e na América. ${ }^{16}$

10 BOBBIO, Norberto. A Teoria das Formas de Governo. Brasília: Universidade de Brasília, 1984, p. 45-64; ARISTÓTELES. Ética a Nicômaco. São Paulo: Martin Claret, 2001, p. 186-187; PLATÃo. A República. São Paulo: Martin Claret, 2001, p. 259-263; DURANT, Will. História da Filosofia, p. 41 e 107; BOBBIO, Norberto. Teoria Geral da Política: a filosofia política e as lições dos clássicos. Rio de Janeiro: Campus, 2000, p. 375.

11 COULANGES, Fustel. A Cidade Antiga. São Paulo: Martin Claret, 2001, p. 248-251.

12 BOBBIO, Norberto. Teoria Geral da Política: a filosofia política e as lições dos clássicos, p. 380-381;

13 DUSSEL, Enrique. Ética da Libertação: na idade da globalização e da exclusão. Petrópolis: Vozes, 2000, p. 62-63. BOBBIO, Norberto. Direito e Estado no Pensamento de Emanuel Kant. São Paulo: Mandarim, 2000, p. 212-213.

14 BOBBIO, Norberto. Teoria Geral da Política: a filosofia política e as lições dos clássicos, p. 371; BIELSCHWSKY, Raoni. Democracia Constitucional, p. 53. Ainda neste sentido, Raoni Bielschwsky, p. 83: "A liberdade dos modernos, negativa, que encontra sua proteção no Estado de Direito, representando a redenção do poder perante o indivíduo. E a liberdade dos antigos, que encontra no exercício democrático do poder, no princípio da soberania popular sua efetivação e livre participação do indivíduo nas tomas de decisão coletiva."

15 DAHL, Robert. Sobre a Democracia. Brasília: Universidade de Brasília, 2001, p. 27-35.

16 BIELSCHWSKY, Raoni. Democracia Constitucional, p. 52. 
Por mais que esta compreensão da democracia representativa esteja presente e fortemente institucionalizada há mais de dois séculos, somente 22 países possuem instituições democráticas ininterruptas desde a década de 50 do século passado: Alemanha, Austrália, Áustria, Bélgica, Canadá, Costa Rica, Dinamarca, Estados Unidos, Finlândia, França, Irlanda, Islândia, Israel, Itália, Japão, Luxemburgo, Holanda, Noruega, Nova Zelândia, Reino Unido, Suécia e Suiça. ${ }^{17}$ É natural que no decorrer da história a democracia tenha altos e baixos e sofra as mais contundentes críticas, como se pode exemplificar com Carl Schmitt e sua análise da democracia parlamentar alemã na segunda década do século passado. ${ }^{18}$

Não obstante a etimologia da palavra democracia remeta ao grego e a um significado simples (demos + kratia ou povo + poder), a sua definição ainda é variável, até mesmo porque este poder do povo é conformado pelas ordens constitucionais de cada Estado. Entretanto, parece possível identificar alguns elementos, sob uma perspectiva procedimental, segundo Norberto Bobbio: a) cidadãos maiores de idade com direitos políticos, sem restrições; b) voto igualitário e livre para todos; c) disputa aberta entre as forças políticas e os seus candidatos; d) observância da regra da maioria numérica; e) a maioria não pode limitar os direitos políticos da minoria. ${ }^{19}$ Robert Dahl utiliza a expressão poliarquia ou democracia poliárquica - governo de muitos - em vez de simplesmente democracia, uma expressão considerada por ele mais adequada para o regime do povo em estados extensos e populosos, ou seja, para democracias em escala. Para o autor, há condições essenciais e favoráveis à democracia poliárquica: controle civil das forças militares, por pessoas eleitas; cultura política e convicções democráticas; inexistência de controle estrangeiro contrário ao regime democrático; economia de mercado; fraco pluralismo subcultural. ${ }^{20}$

Em qualquer situação, os procedimentos democráticos devem estar limitados constitucionalmente, numa perspectiva substancial, com base nos direitos fundamentais, o que pode ser chamado de democracia constitucional, até

17 DAHL, Robert. Sobre a Democracia, p. 136.

18 SCHMITT, Carl. A Crise da Democracia Parlamentar. São Paulo: Scritta, 1996, p. 8-9.

19 BOBBIO, Norberto. Teoria Geral da Política: a filosofia política e as lições dos clássicos, p. 427.

20 DAHL, Robert. Sobre a Democracia, p. 103 e 162. 
mesmo porque a Constituição é o espaço para a organização do poder político do Estado: "a democracia constitucional é um regime formal e materialmente moldado e estabelecido a partir de um compromisso teleológico com a dignidade da pessoa humana." ${ }^{21}$ Não é outro o posicionamento de Canotilho, para quem, da mesma forma que o princípio do Estado de Direito, o princípio democrático "é um princípio jurídico-constitucional com dimensões materiais e dimensões organizativo-procedimentais.".

A própria compreensão de Estado de Direito resta alterada, não somente focada na observância da lei - aspecto formal, mas imbuído das finalidades da própria ordem constitucional, como os direitos fundamentais, para o qual a participação do cidadão e da sociedade é imprescindível. É uma forma de aproximar o Estado da sociedade, de trazer maior legitimidade na atuação estatal, de efetivar um maior controle social sobre as funções estatais e para a própria efetivação dos direitos fundamentais. ${ }^{22}$

Isso porque o princípio democrático é um princípio complexo que abarca tanto a teoria democrática representativa quanto a democracia participativa, a apontar no caminho de um processo de democratização em todos os aspectos da vida social. ${ }^{23} \mathrm{Num}$ sentido constitucional a democracia é uma "democratização da democracia." ${ }^{24}$ Neste contexto, Fabiana de Menezes Soares afirma que o conceito de democracia está alicerçado "na soberania popular (poder emanado do povo) e na participação popular, no exercício do poder de forma indireta e direta; é o

21 BIELSCHWSKY, Raoni. Democracia Constitucional, p. 89.

22 PEREZ, Marco Augusto. Institutos de Participação Popular na Administração Pública. Dissertação, USP, 2001, p. 45-49.

23 BARROSO, Luis Roberto. Curso de Constitucional Contemporâneo: os direitos fundamentais e a construção do novo modelo. São Paulo: Saraiva, 2009. In verbis, p. 91: "Na configuração moderna do Estado e da sociedade, a ideia de democracia já não se reduz à prerrogativa popular de eleger representantes, nem tampouco às manifestações das instâncias formais do processo majoritário. Na democracia deliberativa, o debate público amplo, realizado em contexto de livre articulação de ideias e de informações, e observado o respeito aos direitos fundamentais, desempenha uma função racionalizadora e legitimadora de determinadas decisões políticas."

24 CANOTILHO, J.J. Gomes. Direito Constitucional e Teoria da Constituição. 3. ed. Coimbra: Almedina, 1999, p. 282-284. In verbis, p.282: "Em segundo lugar o princípio democrático implica democracia participativa, isto é, a estruturação de processos que ofereçam aos cidadãos efectivas possibilidades de aprender a democracia, participar nos processos de decisão, exercer controlo crítico na divergência de opiniões, produzir inputs políticos democráticos." 
princípio participativo." ${ }^{25}$ Este princípio participativo nada mais é, nas lições de José Afonso da Silva, do que a "participação direta e pessoal da cidadania na formação dos atos de governo."26

Para Paulo Bonavides a democracia participativa representa um terceiro momento da teoria constitucional e está esculpida nos art. $1^{\circ}$ e 14 da Constituição, mormente no conceito de soberania, a buscar uma repolitização da legitimidade, a figurar o cidadão como "medula da legitimidade de todo o sistema". Mais do que isto, com a democracia participativa "o político e o jurídico se coagulam na constitucionalidade enquanto simbiose de princípios, regras e valores, que fazem normativo o sistema". ${ }^{27}$ Em sentido similar, quanto à relação da legitimidade com a democracia participativa, Luís Roberto Barroso afirma o caráter deliberativo das democracias contemporâneas, na qual a legitimidade do poder é aferida pela participação social em espaços de diálogo e ajustes, a reforçar a espacialidade pública não estatal. ${ }^{28}$ Trata-se de um imperativo democrático. ${ }^{29}$

É neste sentido que a Constituição Federal de 1988 concebe o princípio democrático, a fortalecer não somente a democracia representativa, mas também a democracia participativa, cuja conceituação imbrica-se com o próprio Estado Democrático de Direito. Abarca, também, a democracia direta, passível de viabilização nos casos de referendo e plebiscito. ${ }^{30}$ Trata-se de um dos caminhos para a concretização do princípio da legitimidade da atuação estatal. ${ }^{31}$ Conforme aduz Juarez Freitas, a boa administração, elevada à condição de direito fundamental, 25 SOARES, Fabiana de Menezes. Direito Administrativo de Participação: cidadania, direito, estado, município. Belo Horizonte: Del Rey, 1997, p. 68.

26 SILVA, José Afonso. Curso de Direito Constitucional Positivo. 6. ed. São Paulo: Revista dos Tribunais, 1990, p.125

27 BONAVIDES, Paulo. Teoria Constitucional da Democracia Participativa: por um Direito Constitucional de luta e resistência; por uma nova hermenêutica; por uma repolitização da legitimidade. São Paulo: Malheiros, 2001, p. 33-42.

28 BARROSO, Luis Roberto. Curso de Constitucional Contemporâneo: os direitos fundamentais e a construção do novo modelo, p. 62.

29 LEAL, Rogério Gesta. Participação Social na Administração Pública: um imperativo democrático. In: HERMANY, Ricardo (Org.). Empoderamento Social Local. Santa Cruz: Editora IPR, 2010, p. 51-76.

30 Art. 14 da Constituição Federal e Lei 9.079/98.

31 Constituição Federal: "Art. 70. A fiscalização contábil, financeira, orçamentária, operacional e patrimonial da União e das entidades da administração direta e indireta, quanto à legalidade, legitimidade, economicidade, aplicação das subvenções e renúncia de receitas, será exercida pelo Congresso Nacional, mediante controle externo, e pelo sistema de controle interno de cada Poder." 
tem o seu pressuposto numa administração dialógica que respeita a participação social: "o Estado-Administração da discricionariedade legítima requer (ao mesmo tempo, suscita) o protagonismo da sociedade amadurecida e do agente público que promove o 'bem de todos'." 32

O Estado Democrático de Direito, conformado pela Constituição Federal de 1988, busca efetivar o princípio democrático, tanto na perspectiva representativa quanto na perspectiva participativa, com procedimentos a serem observados, sem olvidar a conteudística constitucional vinculante a todos os poderes, em todos os níveis da federação e às relações privadas, calcada nos direitos fundamentais.

\section{A POLÍTICA NACIONAL DE PARTICIPAÇÃO SOCIAL INSTITUÍDA PELO DECRETO 8.243/2014}

Se o objetivo destas considerações é analisar a (in)constitucionalidade do Decreto 8.243/2014, essencial é que se faça a análise deste ato normativo.

A publicação do decreto ocorreu no dia 23 de maio de 2014 a fim de instituir a política nacional de participação social (PNPS) e o sistema nacional de participação social (SNPS) para a administração pública federal.

O decreto foi assinado pela Presidente da República, Dilma Roussef; pela Ministra do Planejamento, Orçamento e Gestão, Miriam Belchior; pelo Ministro-Chefe da Secretaria Geral da Presidência da República, Gilberto Carvalho; e pelo Ministro de Estado Chefe da Controladoria-Geral da União, Jorge Hage Sobrinho. Fundamentouse a competência para a sua edição no art. 84, IV e VI da Constituição e no art. $3^{\circ}$, caput, inciso I e no art. 17 da Lei 10.683/2003. Abrange, conforme seu art. 5, os órgãos da administração federal direta e respectivos entes da administração indireta. À pormenorização das questões mais relevantes deste decreto.

$\mathrm{O}$ art. $1^{\circ}$ institui a política nacional de participação social com o objetivo de "fortalecer e articular os mecanismos e as instâncias democráticas de diálogo e 
a atuação conjunta entre a administração pública federal e a sociedade civil"33, que deve ocorrer na formulação, execução, monitoramento e avaliação das mais diversas políticas públicas, bem como no aprimoramento da gestão.

$\mathrm{O}$ art. $2^{\circ}$ conceitua a sociedade civil e os diversos instrumentos de participação e controle social: conselho de políticas públicas, comissão de políticas públicas, conferência nacional, ouvidoria pública federal, mesa de diálogo, fórum interconselhos, audiência pública, consulta pública e ambiente virtual de participação social. Estes mecanismos são citados novamente no art. $6^{\circ}$ deste ato normativo.

Os art. $3^{\circ}$ e $4^{\circ}$ apresentam as diretrizes e os objetivos da política nacional de participação social, a salientar a integração da democracia representativa, participativa e direta; a participação social como um direito do cidadão e como método de governo; o direito à transparência e ao controle social; a busca da cidadania ativa; o fortalecimento da sociedade civil e a melhora da relação com o governo; o estímulo ao uso das novas tecnologias, como a internet; o incentivo à participação de grupos de excluídos e vulneráveis; a promoção da capacitação dos agentes públicos e da sociedade para a participação; e o impulso para que todos os entes federados assim atuem.

$\mathrm{O}$ art. $7^{\circ}$ discorre sobre o sistema nacional de participação social, composto basicamente pelos conselhos de políticas públicas, comissões de políticas públicas, conferências nacionais, ouvidorias federais, mesas de diálogo e fóruns interconselhos.

O órgão central da PNPS e SNPS é a Secretaria-Geral da Presidência da República, com as atribuições de acompanhar, orientar, realizar estudos e audiências para a melhor implantação possível do PNPS e SNPS, assessorado pelo Comitê Governamental de Participação Social, criado no decreto, a ser disciplinado. São as disposições dos art. $8^{\circ}$ e $9^{\circ}$ do decreto.

Os art. 10 a 18 apresentam disposições gerais de organização e funcionamento dos mecanismos da política e do sistema nacional de participação social. Os conselhos de políticas públicas, a observar demais disposições legais incidentes, 33 Art. $1^{\circ}$ do Decreto 8.243/2014. 
devem buscar a participação paritária entre os representantes da sociedade e do governo, de forma diversificada e com critérios transparentes na escolha rotativa dos seus integrantes. Além disso, devem consultar a sociedade sobre a sua estruturação e competências, além de pugnar pela publicidade dos seus atos. Reafirma-se a não remuneração na participação destes conselhos a configurar serviço público relevante. Os conselhos deliberativos ficam a depender, para a publicação das suas resoluções, da análise da legalidade por órgão competente. A fim de resguardar a impessoalidade, proíbe-se o voto de conselheiro ligado à entidade que possa ser beneficiada com o repasse de recursos.

As comissões de políticas públicas diferem basicamente dos conselhos em razão da existência de prazo determinado para as suas atividades, tema e objetivos específicos a serem buscados. As ouvidorias devem observar as diretrizes da Ouvidoria-Geral da União.

As conferências nacionais, convocadas por ato específico, após manifestação do Comitê Governamental de Participação Social, devem ter ampla divulgação do documento convocatório e respectivos procedimentos operacionais e de funcionalidade, diversidade dos representantes participantes, critérios de escolha de delegados governamentais e da sociedade civil, integração com as etapas em noutros níveis da federação, acompanhamento das suas resoluções e ampla publicidade dos seus atos.

Já as mesas de diálogo, com prazo determinado de funcionamento, buscam a resolução de problemas decorrentes das relações de trabalho, logo, com a participação dos empregados, dos empregadores e do governo, com o acompanhamento das soluções ajustadas pelos partícipes.

Os fóruns interconselhos devem ter por foco uma determinada política ou programa que requeiram um debate intersetorial para a sua formulação ou acompanhamento, com a participação de conselhos e entidades da sociedade civil. As suas recomendações e os demais resultados devem ser amplamente publicizados.

As audiências públicas devem ter um instrumento convocatório com objeto, metodologia e data para a realização facilmente acessível a todos. As contribuições 
recebidas devem ser sistematizadas e publicadas sem deixar de responder a todas as propostas recebidas. As consultas públicas devem observar os mesmos requisitos das audiências públicas, porém, com o dever de utilizar as ferramentas da internet, logo, num processo mais formal e escrito, enquanto que na audiência privilegia-se a oralidade.

Também há os ambientes virtuais de participação social para o estímulo à participação direta da sociedade civil nas decisões governamentais em ambientes criados para este fim de forma aberta e pública. Além disso, prevê-se a integração com os instrumentos presenciais, seja para a participação pela internet em tempo real, seja para registro.

Por fim, o art. 19 cria a Mesa de Monitoramento das Demandas Sociais, instância interministerial, com o objetivo de acompanhar as demandas dos movimentos sociais.

\section{A (IN)CONSTITUCIONALIDADE DA POLÍTICA E DO SISTEMA DE PARTICIPAÇÃO SOCIAL}

O ponto fulcral deste artigo é a análise da (in)constitucionalidade da PNPS e SNPS instituídos pelo Decreto 8.243/2014. Para tanto, estudar-se-á a sua constitucionalidade formal e material. A primeira, a ponderar se esta política pública e respectivo sistema poderiam ter sido criados por decreto presidencial, sem a dependência de lei aprovada pelo Congresso Nacional. A segunda tem por escopo compreender se o conteúdo do respectivo decreto afronta, materialmente, dispositivos constitucionais.

No que tange à constitucionalidade formal o próprio decreto, no seu preâmbulo, traz a sua fundamentação no art. 84, IV e VI da Constituição, o art. $3^{\circ}$, caput, inciso I e o art. 17 da Lei 10.683/2003. Por partes.

O art. 84 define competências privativas da presidência da república, no caso do inciso IV, para o caso em comento, a competência para a elaboração de decretos para fins de regulamentação; no caso do inciso VI, a competência para 
a edição dos chamados decretos ou regulamentos autônomos. Aos poucos. ${ }^{34}$

A doutrina administrativista, ao estudar os poderes da administração pública, há muito se debruça sobre o chamado poder regulamentar ou normativo, a conferir, à administração, o poder para expedir regulamentos, por meio de decreto, visando à fiel execução de uma determinada lei. ${ }^{35}$

Para o exercício do poder regulamentar ou normativo é necessário a existência de uma lei a ser regulamentada. No caso em tela, conforme o citado preâmbulo do decreto 8.423/2014, estar-se-ia a regulamentar o art. $3^{\circ}$, inciso I da Lei 10.683/2003. ${ }^{36}$ Observa-se que, dentre as competências da Secretaria-Geral da Presidência da República, encontra-se expressamente previsto não somente o relacionamento com a sociedade civil, mas também a criação e a implementação de instrumentos de consulta e participação popular.

Pode-se perguntar se a política e o sistema nacional de participação social podem ser enquadrados como instrumentos de consulta e participação social. Lembra-se de que este decreto também dispõe, para a administração federal, de instrumentos específicos, como os conselhos de políticas públicas, as comissões de políticas públicas, as conferências nacionais, as ouvidorias federais, as mesas de diálogo, os fóruns interconselhos, as audiências públicas, as consultas públicas e os ambientes virtuais de participação social. Salienta-se, desde já, 34 Constituição Federal: "Art.84. Compete privativamente ao Presidente da República: IV sancionar, promulgar e fazer publicar as leis, bem como expedir decretos e regulamentos para sua fiel execução; VI - dispor, mediante decreto, sobre: a) organização e funcionamento da administração federal, quando não implicar aumento de despesa nem criação ou extinção de órgãos públicos; b) extinção de funções ou cargos públicos, quando vagos;"

35 MEIRELLES, Hely Lopes. Direito Administrativo Brasileiro. 20. ed. São Paulo: Malheiros, 1993, p. 111; MELLO, Celso Antônio Bandeira de. Curso de Direito Administrativo. 20. ed. São Paulo: Malheiros, 2006, p. 317; DI PIETRO, Maria Zylvia. Direito Administrativo. 27. ed. São Paulo: Atlas, 2014, p. 92; CARVALHO FILHO, José dos Santos. Manual de Direito Administrativo. 27. ed. São Paulo: Atlas, 2013, p. 57; ARAÚJO, Edmir Netto de. Curso de Direito Administrativo. São Paulo: Saraiva, 2005, p. 420; NOHARA, Irene Patrícia. Direito Administrativo. 3. ed. São Paulo: Atlas, 2013, p. 130; MEDAUAR, Odete. Direito Administrativo Moderno. 17. ed. São Paulo: Revista dos Tribunais, 2013, p. 132; GASPARINI, Diógenes. Direito Administrativo. 10. ed. São Paulo: Saraiva, 2005, p. 117; PESTANA, Marcio. Direito Administrativo Brasileiro. Rio de Janeiro: Elsevier, 2008, p. 206; MORAES, Alexandre de. Direito Constitucional Administrativo. 3. ed. São Paulo: Atlas, 2013,p. 75-76.

36 Lei 10.683/2003: "Art. 30 À Secretaria-Geral da Presidência da República compete assistir direta e imediatamente ao Presidente da República no desempenho de suas atribuições, especialmente: I - no relacionamento e articulação com as entidades da sociedade civil e na criação e implementação de instrumentos de consulta e participação popular de interesse do Poder Executivo;" 
que tais mecanismos não vinculam a administração pública, mas trazem uma maior porosidade à participação e ao controle social no processo de formulação, execução e avaliação de políticas públicas.

Importantes estudos sobre a democracia participativa e seus instrumentos já trilharam este caminho. Marcos Perez apresenta uma classificação que tem por base a obrigatoriedade ou não da administração pública seguir as deliberações da população. Para tanto, apresenta instrumentos vinculantes (referendo, plebiscito, conselhos deliberativos e eleição para funções de chefia, direção ou confiança), não vinculantes (audiência pública, consulta pública, orçamento participativo e ouvidoria) e os não vinculantes e autônomos (organizações não governamentais, utilidade pública, organizações sociais e serviços sociais autônomos). ${ }^{37}$ No mesmo sentido Giovani Corralo ao discorrer sobre estes instrumentos em nível municipal. ${ }^{38}$ Fabiana Menezes Soares estuda as audiências, as consultas, os conselhos, o orçamento participativo e as ouvidorias ou ombudsman. ${ }^{39}$

É possível vislumbrar, sem dúvidas, que os mecanismos disciplinados pelo Decreto 8.423/2014 enquadram-se perfeitamente como instrumentos de participação, consulta e controle social na administração pública, a permitir, desta forma, o uso do decreto a fim de regulamentar o art. $3^{\circ}$, caput e inciso I da Lei $10.683 / 2003$. Não se vislumbra excesso ou abuso no exercício do poder regulamentar, que deve observar "limites formais, legais e constitucionais." ${ }^{40}$ Quanto ao limite formal, foi adequadamente expedido pela Presidente da República, juntamente com os ministros competentes; quanto ao limite legal e constitucional, concretizou-se uma lei federal constitucional - formalmente e materialmente, sem ultrapassar os seus limites, no caso, a Lei 10.683/2003. No mesmo sentido, não se vislumbram traços de um decreto regulamentar ultra legem, contra legem ou citra legem, também de observância obrigatória nestes

37 PEREZ, Marco Augusto. Institutos de Participação Popular na Administração Pública, p. 117-175.

38 CORRALO, Giovani. A Democracia Participativa nos Municípios Brasileiros. In: HERMANY, Ricardo (Org.). Empodrramento Social Local. Santa Cruz: Editora IPR, 2010, p. 289306.

39 SOARES, Fabiana de Menezes. Direito Administrativo de Participação: cidadania, direito, estado, município, p. 92-105, 137-175 e 206-219.

40 GASPARINI, Diógenes. Direito Administrativo, p. 119. 
atos normativos ${ }^{41}$ pois não inovou a ordem jurídica, não contrariou o sentido da lei regulamentada e nem houve a supressão de direitos. É um decreto elaborado secundum legem, ou seja, consoante a legislação.

Entretanto, não obstante a argumentação feita, o preâmbulo do decreto em estudo também traz a fundamentação no art. 84, VI da Constituição. ${ }^{42}$ Este inciso traz para o ordenamento jurídico brasileiro o que alguns denominam regulamento ou decreto autônomo, ou seja, o exercício de um poder normativo pela administração pública, nas duas situações expressas, que não necessita da existência de uma lei anterior, a valer e vigorar por si. ${ }^{43}$

No caso em comento se poderia admitir, unicamente, o exercício deste poder normativo com fundamento na alínea "a" do inciso VI do art. 84 da Constituição, uma vez que não deixa de dispor sobre a organização e o funcionamento da administração federal. Não há a criação de despesa pública, nem a criação ou a extinção de órgão público. O decreto regulamentar autônomo não pode invadir a reserva de lei:

(...) advirta-se que a razoabilidade/proporcionalidade é parâmetro que serve para limitar a edição de decretos que extrapolem o sistema da reserva leal ou que, a pretexto de regulamentar dado direito, fulminem o núcleo essencial das liberdades públicas. ${ }^{44}$

Observa-se que o decreto em tela disciplina a organização e o funcionamento da administração pública, sem extrapolar os limites legais e constitucionais. Traz a necessidade imperiosa de a administração pública auscultar os interessados cidadãos e sociedade civil organizada, quando da formulação, execução e avaliação de políticas públicas. Novamente, reforça-se a não vinculação à administração pública no uso dos instrumentos previstos no Decreto 8.423/2014, nem a

41 NOHARA, Irene Patrícia. Direito Administrativo, p. 133; DI PIETRO, Maria Zylvia. Direito Administrativo, p. 92; MELLO, Celso Antônio Bandeira de. Curso de Direito Administrativo, p. 318-321.

42 Constituição Federal: "Art. 84. Compete privativamente ao Presidente da República: VI dispor, mediante decreto, sobre: a) organização e funcionamento da administração federal, quando não implicar aumento de despesa nem criação ou extinção de órgãos públicos; b) extinção de funções ou cargos públicos, quando vagos;"

43 DI PIETRO, Maria Zylvia. Direito Administrativo, p. 94; GASPARINI, Diógenes. Direito Administrativo, p. 122; NOHARA, Irene Patrícia. Direito Administrativo, p.133-136.

44 NOHARA, Irene Patrícia. Direito Administrativo. p. 135. 
substituição do imprescindível papel do Congresso Nacional para a instituição e a alteração de políticas públicas.

Por fim, resta a avaliação da compatibilidade material dos dispositivos do decreto em reflexão com os mandamentos constitucionais. Isso porque a Constituição Federal se encontra no vértice do ordenamento jurídico, com "mandatos jurídicos obrigatórios (...) possuem uma especial força de obrigar, uma vez que a Constituição é a forma suprema de todo o ordenamento jurídico." ${ }^{45}$

Conforme exposto no desenvolvimento inicial desta pesquisa, o princípio democrático alicerça o Estado Democrático de Direito consignado na Constituição Federal de 1988. Este alicerce está cimentado não somente nos postulados da democracia representativa e democracia direta (a considerar o plebiscito e o referendo), mas também na democracia participativa, essencial para a legitimação do agir estatal, especialmente no exercício da função administrativa.

A democracia participativa não vem a substituir ou desconsiderar a democracia representativa, mas a fortalecê-la, a trazer inputs e outputs legitimadores e democratizantes. Com fulcro no princípio da unidade da Constituição, da força normativa e da interpretação conforme a Constituição ${ }^{46}$, é possível apontar para constitucionalidade material dos dispositivos do Decreto 8.423/2014, até mesmo porque, nas palavras de Juarez Freitas "uma pertinente e adequada interpretação sistemática só declara a inconstitucionalidade quando a afronta ao sistema revelarse manifesta e insanável"47, o que está longe de figurar neste estudo. As normas deste decreto encontram-se em plena harmonia com os princípios constitucionais do Estado Democrático de Direito e consequente princípio democrático.

Talvez, e apenas para constar, a resistência a este ato normativo tenha por base uma tradicional aversão de uma elite ou seus defensores ${ }^{48}$ - esta mesma $\overline{45}$ STRECK, Lênio. Hermenêutica Jurídica e(m) Crise. 2. ed. Porto Alegre: Livraria do Advogado, 2000, p. 288.

46 MENDES, Gilmar Ferreira; COLEHO, Inocêncio Mártires; BRANCO, Paulo Gustavo Gonet. Curso de Direito Constitucional. 4. ed. São Paulo: Saraiva, 2009, p. 132-143

47 FREITAS, Juarez. A Interpretação Sistemática do Direito. 3. ed. São Paulo: Malheiros, 2002, p. 218.

48 AZEVEDO, Reinaldo. Blog - Revista Veja. Disponível em: <http://veja.abril.com.br/blog/ reinaldo/tag/decreto-8-243/>. Acesso em 25. Jul. 2014; BOLSONARO, Jair. Ação Popular. Disponível em: <http://www.flaviobolsonaro.com.br/documentos/ap_dec_8243_bolsonaro.pdf>. Acesso em: 24. Jul. 2014. 
condenada por Darcy Ribeiro como as responsáveis pelo desenvolvimento tardio nacional por defender unicamente os seus interesses, ${ }^{49} \mathrm{com}$ as costas ao povo - em aceitar que as pessoas do povo, individualmente ou organizadas, tenham a possibilidade de participar do processo político e decisório nacional. Isso que o Decreto 8.423/2014, frisa-se mais uma vez, não vincula a administração pública a esta participação. Similarmente, Paulo Bonavides aduz, ao discorrer sobre o bloqueio das classes dominantes à democracia participativa, que a "elite hegemônica desfruta do poder, sempre em proveito próprio, fazendo do povo ícone a base moral do status quo e da legitimação." 50

Ao deixar de lado as críticas oriundas de posturas reacionárias, afirma-se, com fundamento na Constituição Federal, formalmente e materialmente, a constitucionalidade do Decreto 8.423/2014, que institui a política nacional de participação social e o sistema nacional de participação social.

\section{CONSIDERAÇÕES FINAIS}

Com base nas reflexões feitas nos capítulos deste artigo é possível chegar às seguintes conclusões:

I - O Estado Democrático de Direito esculpido na Constituição Federal de 1988 encontra-se alicerçado no princípio democrático. Significa afirmar a inabdicabilidade da democracia como pressuposto de organização do sistema jurídico e político nacional.

II - Observa-se que a própria democracia tem sofrido mutações conceituais no decorrer do tempo. O seu surgimento remonta à Grécia clássica, há aproximadamente dois mil e quinhentos anos, com fulcro na chamada democracia direta, centrada na participação de todos os cidadãos nos debates e nas decisões dos assuntos da cidade. Este modelo foi substituído pela chamada democracia dos modernos, de cunho representativo, na qual se outorga aos eleitos a competência

49 RIBEIRO, Darcy. Ensaios Insólitos. Porto Alegre: L \& PM, 1979, p. 11-19.

50 BONAVIDES, Paulo. Teoria Constitucional da Democracia Participativa: por um Direito Constitucional de luta e resistência; por uma nova hermenêutica; por uma repolitização da legitimidade, p. 54. 
para decidir em nome do povo. A escolha ocorre em processos periódicos e abertos à participação de todos os que se enquadrem nos requisitos legais. $A$ democracia direta dos antigos cede à democracia representativa dos modernos.

III - Entretanto, a democracia representativa não tem sido suficiente, por si, para aferir a legitimidade requerida à atuação estatal e promover um processo mais profundo de democratização da própria sociedade. Em razão disso, o constitucionalismo contemporâneo tem reafirmado, nas últimas décadas, que o princípio democrático abarca, necessariamente, a democracia participativa. Não se trata de uma forma de substituir a lógica representativa, mas de agregar espaços de participação às pessoas do povo, a integrar a representação com a participação.

IV - No Estado Democrático de Direito conformado pela Constituição de 1988 o princípio democrático possui esta configuração, a reafirmar a democracia representativa e, ao mesmo tempo, promover a participação e o controle social na espacialidade estatal, especialmente na administração pública.

V-Em 23 de maio de 2014 o governo federal publicou o Decreto 8.243/2014, que instituiu a política nacional de participação social e o respectivo sistema nacional de participação social. De imediato houve uma grande repercussão midiática e nos meios políticos daqueles que compreende ser este decreto inconstitucional, a grande maioria oriunda de setores conservadores da sociedade. Parece haver uma reação contrária à possibilidade das pessoas do povo - individualmente ou organizadas - de participar do processo político e decisório nacional.

VI - A centralidade da política e do sistema nacional de participação social está na utilização de instrumentos para que as pessoas do povo e a sociedade civil organizada possam participar efetivamente do processo de elaboração, execução, monitoramento e avaliação de políticas públicas. Estes mecanismos, a serem utilizados por órgãos da administração direta e entes da administração indireta federal, consistem em conselhos de políticas públicas, comissões de políticas públicas, conferências nacionais, ouvidorias públicas, mesas de diálogo, fóruns interconselhos, audiências públicas, consultas públicas e ambientes virtuais de participação social. 
VII - A análise da constitucionalidade do Decreto 8.243/2014 é o foco deste trabalho científico. Para tanto, analisou-se a constitucionalidade formal e material.

VIII - Formalmente, com base na fundamentação do próprio decreto, a competência para a sua elaboração encontra-se nos art. 84, IV e VI da Constituição Federal. O inciso IV do art. 84 remete à competência privativa do Presidente da República em utilizar o poder regulamentar a fim de emitir decretos e respectivos regulamentos para a fiel execução de uma determinada lei. Salienta-se, mais uma vez, que o decreto em comento traz mecanismos de participação e controle social na administração pública e que a lei regulamentada - art. $3^{\circ}$, caput e inciso I da Lei 10.683/2003 - efetivamente confere este poder à Secretaria-Geral da Presidência da República, competente para agir na articulação com a sociedade civil e para criar e implementar instrumentos de participação popular. Não se vislumbra afronta aos limites formais e matérias no exercício deste poder regulamentar.

IX - No mesmo sentido, também na perspectiva formal, em relação ao aduzido inciso VI do art. 84, do qual importa somente a sua alínea "a", a permitir ao Presidente da República dispor, via decreto, sobre a organização e o funcionamento da administração federal, desde que não crie despesa e não extinga ou crie órgãos públicos. No caso em questão, poder-se-ia considerar, também, o decreto em análise como o exercício de um poder normativo, seja porque disciplina os mecanismos por meio dos quais a população e a sociedade organizada podem participar nas políticas públicas, seja porque esta participação popular não vincula, prima facie, a administração federal.

X-Por fim, quanto à materialidade do decreto, vê-se a sua total compatibilidade comoEstadoDemocrático deDireitoe respectivo princípio democrático, afortalecer a democracia participativa, sem conflitar com a democracia representativa e direta (a considerar o plebiscito e o referendo) previstas na Constituição de 1988. Empoderam-se os cidadãos e a sociedade civil organizada para se obter maiores graus de legitimidade na atuação da máquina administrativa nos processos de elaboração, execução, monitoramento e avaliação de políticas públicas. 


\section{REFERÊNCIAS}

ARAÚJO, Edmir Netto de. Curso de Direito Administrativo. São Paulo: Saraiva, 2005.

ARENDT, Arendt. Origens do Totalitarismo: antissemitismo, imperialismo, totalitarismo. São Paulo: Schwarcz, 2013.

ARISTÓTELES. Ética a Nicômaco. São Paulo: Martin Claret, 2001.

AZEVEDO, Reinaldo. Blog - Revista Veja. Disponível em: < http://veja.abril.com.br/blog/ reinaldo/tag/decreto-8-243/>. Acesso em 25. Jul. 2014.

BARROSO, Luis Roberto. Curso de Constitucional Contemporâneo: os direitos fundamentais e a construção do novo modelo. São Paulo: Saraiva, 2009.

BIELSCHWSKY, Raoni. Democracia Constitucional. 1. ed. Saraiva, 2013. VitalBook file. Minha Biblioteca, p.52.Disponívelem:<http://online.minhabiblioteca.com.br/books/9788502196841/ page/52>. Acesso em 15 jul. 2014.

BOBBIO, Norberto. A Teoria das Formas de Governo. Brasília: Universidade de Brasília, 1984.

BOBBIO, Norberto. Teoria Geral da Política: a filosofia política e as lições dos clássicos. Rio de Janeiro: Campus, 2000.

BOBBIO, Norberto. Direito e Estado no Pensamento de Emanuel Kant. São Paulo: Mandarim, 2000.

BOLSONARO, Jair. Ação Popular. Disponível em: < http://www.flaviobolsonaro.com.br/ documentos/ap dec 8243 bolsonaro.pdf $>$. Acesso em 24. Jul. 2014.

CANOTILHO, J.J. Gomes. Direito Constitucional e Teoria da Constituição. 3. ed. Coimbra: Almedina, 1999.

CARVALHO FILHO, José dos Santos. Manual de Direito Administrativo. 27. ed. São Paulo: Atlas, 2013.

CORRALO, Giovani. A Democracia Participativa nos Municípios Brasileiros. In: HERMANY, Ricardo (Org.). Empodramento Social Local. Santa Cruz: Editora IPR, 2010, p. 289-306.

COULANGES, Fustel. A Cidade Antiga. São Paulo: Martin Claret, 2001.

DAHL, Robert. Sobre a Democracia. Brasília: Universidade de Brasília, 2001. 
DI PIETRO, Maria Zylvia. Direito Administrativo. 27. ed. São Paulo: Atlas, 2014.

DURANT, Will. História da Filosofia. São Paulo: Companhia Editora Nacional, 1926.

DUSSEL, Enrique. Ética da Libertação: na idade da globalização e da exclusão. Petrópolis: Vozes, 2000.

FOLHA DE SÃO PAULO ON LINE. Disponível em: <http://www1.folha.uol.com.br/ poder/2014/06/1468178-devido-a-decreto-de-consulta-popular-oposicao-obstruiravotacoes-na-camara.shtml>. Acesso em: 22 jul. 2014.

FREITAS, Juarez. A Interpretação Sistemática do Direito. 3. ed. São Paulo: Malheiros, 2002.

FREITAS, Juarez. Discricionariedade Administrativa e o Direito Fundamental à Boa Administração Pública. São Paulo: Malheiros, 2009.

GASPARINI, Diógenes. Direito Administrativo. 10. ed. São Paulo: Saraiva, 2005.

KELSEN, Hans. A Democracia. São Paulo: Martins Fontes, 2000.

LEAL, Rogério Gesta. Participação Social na Administração Pública: um imperativo democrático. In: HERMANY, Ricardo (Org.). Empodramento Social Local. Santa Cruz: Editora IPR, 2010, p. 51-76.

LUMMIS, C. Douglas. Radical Democracy. Ithaca: Cornell University Press, 1996.

MEDAUAR, Odete. Direito Administrativo Moderno. 17. ed. São Paulo: Revista dos Tribunais, 2013.

MEIRELLES, Hely Lopes. Direito Administrativo Brasileiro. 20. ed. São Paulo: Malheiros, 1993.

MELLO, Celso Antônio Bandeira de. Curso de Direito Administrativo. 20. ed. São Paulo: Malheiros, 2006.

MENDES, Gilmar Ferreira; COLEHO, Inocêncio Mártires; BRANCO, Paulo Gustavo Gonet. Curso de Direito Constitucional. 4. ed. São Paulo: Saraiva, 2009.

MORAES, Alexandre de. Direito Constitucional Administrativo. 3. ed. São Paulo: Atlas, 2013.

NOHARA, Irene Patrícia. Direito Administrativo. 3. ed. São Paulo: Atlas, 2013. 
PEREZ, Marco Augusto. Institutos de Participação Popular na Administração Pública. Dissertação (Mestrado em Direito). Faculdade de Direito. Universidade de São Paulo. São Paulo, 2001.

PÉRICLES. Oração Fúnebre. Disponível em: <http://pt.scribd.com/doc/54079555/ORACAOFUNEBRE-PERICLES>. Acesso em: 10 jul. 2014.

PESTANA, Marcio. Direito Administrativo Brasileiro. Rio de Janeiro: Elsevier, 2008.

PLATÃO. A República. São Paulo: Martin Claret, 2001.

RIBEIRO, Darcy. Ensaios Insólitos. Porto Alegre: L \& PM, 1979.

SCHMITT, Carl. A Crise da Democracia Parlamentar. São Paulo: Scritta, 1996.

SILVA, José Afonso. Curso de Direito Constitucional Positivo. 6. ed. São Paulo: Revista dos Tribunais, 1990.

SOARES, Fabiana de Menezes. Direito Administrativo de Participação: cidadania, direito, estado, município. Belo Horizonte: Del Rey, 1997.

STRECK, Lênio. Hermenêutica Jurídica e(m) Crise. 2. ed. Porto Alegre: Livraria do Advogado, 2000.

ZAGREBELSKY, Gustavo. A Crucificação e Democracia. 1. ed. Saraiva, 2010, p. 32-33. VitalBook file. Minha Biblioteca. Disponível em: < http://online.minhabiblioteca.com.br/ books/9788502141803/page/32. > . Acesso em: 05. Jul. 2014.

Recebido em: jul/2014

Aprovado em: ago/2014 